\title{
PENCEGAHAN PENYEBARAN VIRUS CORONA DI BANDARA MENGGUNAKAN ARTIFICIAL INTELLEGENCE
}

\author{
Destivanesha Rina \\ Program Studi Informatika, Universitas Nasional \\ destivanesharina@gmail.com
}

Submitted March 10, 2020; Revised June 29, 2020; Accepted July 29, 2020

\begin{abstract}
Abstrak
Mengidentifikasi virus corona pada penumpang kedatangan internasional bertujuan untuk mengetahui apakah penumpang tersebut terserang virus corona atau tidak. Virus corona merupakan salah satu masalah kesehatan yang sangat membutuhkan perhatian kita saat ini. Karena virus ini dapat menyebabkan kematian, dan cara penularan virus ini sangat mudah dan cepat. Ada banyak hal yang bisa dilakukan untuk mengurangi terjadinya penyebaran virus ini ke wilayah Indonesia, salah satunya yaitu dengan melakukan identifikasi suhu tubuh pada setiap penumpang kedatangan internasional di bandara. Pada bandara indentifikasi virus ini dilakukan dengan menggunakan Artificial Intellengence. Salah satu hal yang menjadi tujuan pengembangan teknologi kecerdasan buatan (artificial intellegence atau AI) adalah membantu manusia. Ini sering berarti menirukan kemampuan dan kecerdasan orang yang hendak dibantunya atau digantikannya. Alat yang digunakan yaitu Thermal Scanner Camera yang dapat melihat langsung suhu tubuh penumpang. Dan ada beberapa kit yang telah dibuat untuk mengecek langsung apakah terdapat virus corona pada tubuh manusia yaitu dengan menggunakan Rapid Test dan PCR Test. Penelitian ini dilakukan untuk melihat seberapa pentingnya AI (artificial intellegence) dalam membantu mengurangi penyebaran virus corona. Menurut beberapa datayang telah ada, penggunaan Thermal Scanner Camera dapat membantu mengurangi terjadinya penyebaran virus corona di bandara.
\end{abstract}

Kata kunci: artificial, intellegence, ai, virus, corona, camera.

\begin{abstract}
Identifying the corona virus on international arrival passengers aims to find out whether the passenger has the corona virus or not. Corona virus is one of the health problems that really needs our attention now. Because this virus can cause death, and the way the virus is transmitted is very easy and fast. There are many things that can be done to reduce the spread of this virus to the territory of Indonesia, one of which is to identify the body temperature of each passenger on international arrivals at the airport. At the airport the identification of this virus is done by using Artificial Intelligence. One of the things that is the goal of developing artificial intelligence (AI) is to help humans. This often means imitating the abilities and intelligence of the person he is trying to help or replace. The tool used is the Thermal Scanner Camera that can see directly the body temperature of the passenger. And there are several kits that have been made to check directly whether there is a corona virus in the human body by using the Rapid Test and PCR Test. This research was conducted to see how important AI (artificial intelligence) is in helping reduce the spread of corona virus. According to some existing data, the use of Thermal Scanner Camera can help reduce the spread of corona virus at airports.
\end{abstract}

Keywords: artificial, intelligence, AI, virus, corona, camera

\section{PENDAHULUAN}

Kecerdasan Buatan (Artificial Intelligence) merupakan salah satu bagian dari ilmu komputer yang mempelajari bagaimana membuat mesin (komputer) dapat melakukan pekerjaan seperti dan sebaik yang dilakukan oleh manusia bahkan bisa lebih baik daripada yang dilakukan 
manusia. Aplikasi atau program kecerdasan buatan dapat ditulis dalam semua bahasa komputer, baik dalam bahasa C, Pascal, Basic, dan bahasa pemrograman lainnya. Tetapi dalam perkembangan selanjutnya, dikembangkan bahasa pemrograman yang khusus untuk aplikasi kecerdasan buatan yaitu LISP dan PROLOG [1].

Coronavirus adalah sekelompok virus yang bisa menginfeksi sistem pernapasan. Dalam beberapa kasus, virus ini menyebabkan infeksi pernapasan ringan saja, Ditempat lain, virus ini juga dapat menyebabkan radang infeksi pernapasan berat, seperti tuberkulosis paru (TBC), pneumonia, Severe Acute Respiratory Syndrome (SARS) dan Middle-East Respiratory Syndrome (MERS). Infeksi virus Corona atau COVID-19 bisa menyebabkan penderitanya mengalami gejala flu, seperti hidung berair dan meler, sakit kepala, batuk, nyeri tenggorokan, dan demam; atau gejala penyakit infeksi pernapasan berat, seperti demam tinggi, batuk berdahak bahkan berdarah, sesak napas, dan nyeri dada [2].

Bandara merupakan tempat yang harus menjadi perhatian agar virus ini tidak masuk kewilayah Indonesia. Maka dari itu dilakukan pemeriksaan ketat di 135 pintu masuk bandara kedatangan internasional, salah satu nya dengan menggunakan kamera pemantau suhu badan. Sampai saat ini ilmuwan belum memberikan kesimpulan pasti apakah virus ini lebih berbahaya dari virus SARS dan virus MERS, namun telah tercatat kematian akibat virus ini mencapai 56 orang di Wuhan, China [3].

Sementara itu, Indonesia sendiri telah memperketat pengawasan agar virus ini tidak masuk di Indonesia. Karena Indonesia sendiri telah dikepung oleh beberapa negara yang terjangkit virus corona seperti Australia, Malaysia, Singapura, dan Thailand. Untuk itu, pemerintah menutup sementara penerbangan Bali-Wuhan demi mencegah masuknya virus tersebut ke Indonesia. Dalam penulisan ini, penulis bertujuan untuk memberikan edukasi kepada masyarakat Indonesia bahwa kita harus perduli akan virus corona, karena virus itu dapat menyebar secara cepat pada tubuh manusia. Penggunaan komputer yang sangat marak saat ini memiliki fungsi untuk dapat membuat suatu sistem yang akan mempermudah dan mempercepat pekerjaan manusia.

Artificial intellegence atau kecerdasan buatan merupakan pengetahuan dalam ilmu komputer yang dikenal dengan nama AI. AI merupakan ilmu tentang bagaimana membangun suatu sistem komputer yang dapat menunjukkan kecerdasan dalam berbagai cara, bahkan hal yang tidak bisa dilakukan oleh manusia dengan tujuan untuk mempermudah dan mempercepat pekerjaan manusia [1]. Pada awal diciptakannya, komputer hanya difungsikan sebagai alat hitung saja. Namun seiring dengan perkembangan jaman, maka peran komputer semakin mendominasi kehidupan manusia. Komputer tidak lagi hanya digunakan sebagai alat hitung, lebih dari itu, komputer diharapkan untuk dapat diberdayakan untuk mengerjakan segala sesuatu yang bisa dikerjakan oleh manusia [10]. AI atau Kecerdasan Buatan biasa digunakan dalam aplikasi medis untuk membantu menemukan solusi dalam permasalahan medis. Munculnya kecerdasan buatan dalam bidang kesehatan telah memacu untuk pengembangan aplikasi seperti contoh pada proses diagnosa penyakit.

Sistem pakar merupakan salah satu cabang ilmu dari AI. Sistem pakar adalah program AI dengan Knowledge Base atau basis pengetahuan yang didapatkan berdasarkan pengalaman dan pengetahuan para ahli dalam memecahkan suatu permasalahan 
pada bidang tertentu yang didukung oleh mesin inferensi yang akan melakukan pelacakan fakta-fakta sehingga didapatkan sebuah kesimpulan [3]. Sistem pakar adalah suatu program komputer yang dirancang untuk melakukan penalaran seperti layaknya seorang pakar mengenai suatu bidang keahlian tertentu. Ada dua bagian utama yang menyusun sistem pakar, yaitu lingkungan pengembangan dan lingkungan konsultasi yang digunakan oleh pengguna yang bukan pakar dalam memperoleh pengetahuan pakar [3].

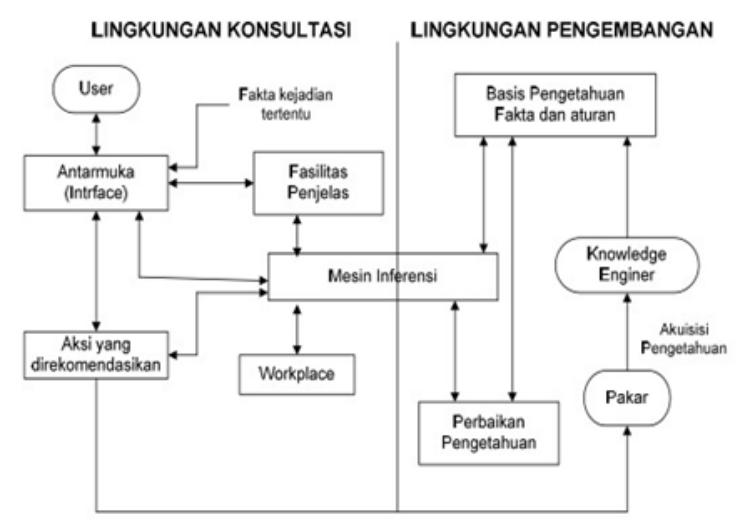

Gambar 1. Arsitektur Sistem Pakar

Ada beberapa metode yang dapat diimplementasikan dalam sistem pakar, diantaranya metode forward chaining, backward chaining, certainty factor, bayes, dan lainnya.

Forward chaining atau yang biasa disebut juga dengan runut maju merupakan proses perunutan yang dimulai dengan menampilkan kumpulan data atau fakta yang meyakinkan menuju konklusi akhir. Runut maju atau yang biasa disebut penalaran foward (Foward Reasoning) atau pencarian data yang dimotori data (data driven search)[5]. Mesin inferensi melakukan pencarian kaidah-kaidah dalam basis pengetahuan yang premisnya sesuai dengan data tersebut, yang kemudian dari kaidah-kaidah tersebut dihasilkan suatu kesimpulan.
Salah satu fitur yang harus dimilki oleh sistem pakar adalah kemampuan untuk menalar.

Jika keahlian-keahlian sudah tersimpan sebagai basis pengetahuan dan sudah tersedia program yang mampu mengakses basis data, maka komputer harus dapat di program untuk membuat referensi. Referensi inilah yang dikemas kedalam bentuk motor referensi atau inference motor.

Ada beberapa langkah yang harus diikuti dalam perangcangan suatu sistem menggunakan sistem pakar, yaitu :

1. Mengambil pengetahuan dari para ahli.

2. Representasi pengetahuan ke komputer.

3. Inferensi pengetahuan.

4. Pengalihan pengetahuan ke pengguna.

\section{METODE PENELITIAN}

Frame Work atau yang biasa disebut dengan kerangka berfikir meliputi kerangka kerja yang dilakukan dalam penelitian. Frame work merupakan penjabaran secara teoritis dari sebuah variabel-variabel yang akan diteliti. Pada penulisan ini penulis menjabarkan frame work dalam bentuk skematis yaitu sebagai berikut :

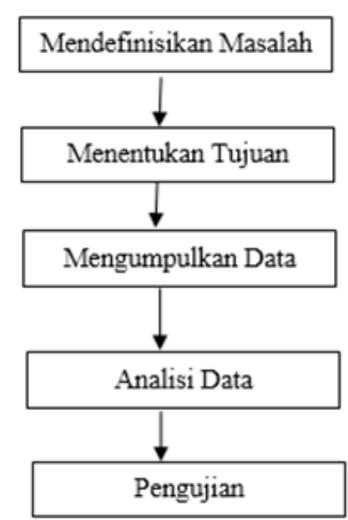

\section{Gambar 2. Tahapan Penelitian}

Berdasarkan frame work diatas dapat dijabarkan bahwa penulisan ini diawali 
dari pendefinisian masalah yang meliputi hasil dari survey yang telah dilakukan dengan mencari data dan informasi yang terdapat dalam internet.

\section{HASIL DAN PEMBAHASAN}

Bandara merupakan salah satu tempat yang menjadi sasaran penting untuk pemerintah mencegah terjadinya penyebaran virus corona masuk ke wilayah Indonesia. Sasaran bandara adalah seluruh penumpang dan yang menjadi sasaran utamanya adalah penumpang kedatangan Internasional karena virus ini bukan berasal dari Indonesia. Virus ini sangat berbahaya bagi orang dengan sistem kekebalan tubuh yang lemah seperti anak kecil dan orang lansia (lanjut usia). Belum ada vaksin yang ditemukan untuk menyembuhkan orang yang tertular virus ini dikarenakan jenis virusnya yang masih baru.

\section{Tabel Hasil}

Pada tabel hasil akan ada 3 klasifikasi dari corona berdasarkan jenis-jenisnya, yaitu :

1. SARS : sindrom pernapasan akut berat adalah penyakit menullar yang disebabkan oleh virus corona SARS-CoV. Ini merupakan bentuk penyakit pneumonia yang dapat menyebabkan kematian.

2. MERS : virus ini disebabkan oleh virus MERS-CoV, yang pertama kali diketahui pada tahun 2012. Penyakit ini dapat menyebar melalui kontak dengan orangorang yang terinfeksi virus MERS.

3. Corona 2019-nCoV : ini merupakan virus yang baru saja diidentifikasi. Banyak orang menyebutnya dengan pneumonia Wuhan karna pertama kali muncul di Wuhan.

Tabel 1. Klasifikasi Corona

\begin{tabular}{lc}
\hline $\begin{array}{l}\text { Kode } \\
\text { Hasil }\end{array}$ & Nama Konklusi \\
\hline K01 & SARS \\
K02 & MERS \\
K03 & Corona2019-CoV \\
\hline
\end{tabular}

\section{Tabel Gejala}

Berikut ini adalah tabel gejala yang akan diidentifikasi :

Tabel 2. Tabel Gejala Fisik

\begin{tabular}{|c|c|c|}
\hline \multirow{2}{*}{$\begin{array}{l}\text { Kode } \\
\text { Hasil }\end{array}$} & \multicolumn{2}{|c|}{ Nama Konklusi } \\
\hline & Virus & Gejala \\
\hline K01 & SARS & \\
\hline & & Batuk Kering \\
\hline K02 & MERS & $\begin{array}{l}\text { Panas Dingin } \\
\text { Diare }\end{array}$ \\
\hline K03 & Corona 2019-CoV & $\begin{array}{c}\text { Sesak Nafas } \\
\text { Rasa Sakit atau Ngilu }\end{array}$ \\
\hline
\end{tabular}

\section{Tabel Penyebab}

Berikut ini adalah tabel penyebab terjadinya virus corona yang dapat menyerang tubuh manusia :

Tabel 3. Tabel Penyebab

\begin{tabular}{cccc}
\hline K01 & K02 & K03 & Penyebab \\
\hline & & & $\begin{array}{c}\text { Melakukan kontak } \\
\text { fisik dengan orang } \\
\text { yang terinfeksi virus } \\
\text { corona }\end{array}$ \\
\hline
\end{tabular}

Dari tabel diatas dapat disimpulkan bahwa penyebab terjadinya semua jenis corona memiliki kesamaan. Selebihnya virus ini ditularkan melalui kontak langsung dengan orang yang terinfeksi virus tersebut.

\section{Tabel Solusi}

Berikut ini adalah tabel solusi dari penanganan virus corona :

Tabel 4. Tabel Solusi

\begin{tabular}{|l|l|l}
\hline \multirow{2}{*}{$\begin{array}{l}\text { Kode } \\
\text { Hasil }\end{array}$} & \multicolumn{2}{|c}{ Nama Konklusi } \\
\cline { 2 - 3 } K01 & Virus & $\begin{array}{l}\text { Hal yg Harus } \\
\text { Dilakukan }\end{array}$ \\
\hline K02 & MERS & $\begin{array}{l}\text { Segera datang ke rumah } \\
\text { sakit untuk diperiksa lebih } \\
\text { lanjut } \\
\text { Gunakan masker saat } \\
\text { berpergian }\end{array}$ \\
K03 & $\begin{array}{l}\text { Rajin mencuci tangan } \\
\text { Corona 2019- }\end{array}$ & $\begin{array}{l}\text { Kurangi aktivitas diluar } \\
\text { rumah }\end{array}$ \\
Menutup mulut ketika \\
sedang batuk
\end{tabular}




\section{Thermal Scanner Camera}

Thermal Scanner Camera merupakan suatu kamera yang berfungsi untuk mendeteksi suhu tubuh manusia. Jadi ketika manusia memiliki suhu tubuh yang tinggi atau demam tinggi, maka akan diketahui oleh petugas bandara. Selain sebagai pemantau suhu badan kamera ini juga mampu merekam suhu berbagai objek yang melintas didepan kamera. Kamera in idilengkapi dengan perangkat penukur yang akan menangkap radiasi inframerah yang disebut dengan mikrobolometer. Mikrobolometter bertugas untuk merekam suhu dan kemudian menetapkan piksel ke warna yang sesuai. Di Indonesia sendiri Kementrian Kesehatan telah mengandalkan kamera ini untuk mendeteksi wabah virus corona yang masuk ke wilayah Indonesia. Pada dasarnya pengecekan suhu tubuh yang dilakukan bandara dilaksanakan setelah penumpang turun dari pesawat. Namun secara intensif, Kementrian Kesehatan mengusulkan untuk melakukan pengecekan di pesawat sebelum para penumpang turun untuk mencegah penyebaran virus corona.

Ada 2 macam kamera thermal scanner yang digunakan pada bandara yaitu kamera yang dapat di genggam oleh tangan atau thermal scanner gun dan thermal scanner yang lengkap beserta layar dan kamera pemantau suhu tubuh. Thermal Scanner Gun merupakan kamera pendeteksi suhu tubuh yang dapat digenggam. Kamera ini pada bandara digunakan untuk mendeteksi suhu tubuh manusia sebelum penumpang turun dari pesawat. Salah satu tanda virus corona adalah demam yang tinggi. Manusia bisa dikatakan demam ketika suhu tubuh sudah melewati rata-rata suhu tubuh normal yakni 37,5 derajat. Alat ini berfungsi untuk mendeteksi secara langsung gejala awal dan tanda tanda seseorang terjangkit virus corona.

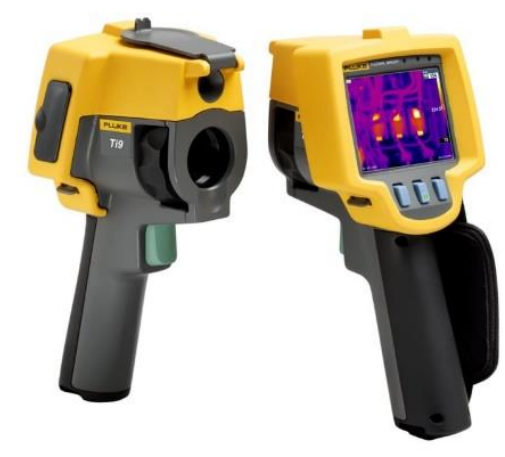

Gambar 3. Thermal Scanner Gun

Thermal Scanner Camera memiliki kamera yang berfungsi untuk melakukan pengecekan suhu di seluruh bagin tubuh. Kamera ini sangat sering digunakan saat wabah SARS pada tahun 2002 dan 2003 lalu. Dan sejak adanya virus corona sekarang hampir di semua bandara di berbagai negara menggunakan kamera ini untuk memindai demam tanpa harus menggunakan termometer. Perangkat thermal camera ini memiliki fitur yang jauh lebih banyak dibandingkan thermal gun karena thermal camera dapat mengidentifikasi suhu di seluruh tubuh dalam kapasitas dan cakupan yang luas. Akan tetapi, thermal scanner tidak mudah untuk dibawa sehingga thermal scanner tidak digunakan untuk mengecek suhu penumpang di dalam pesawat.

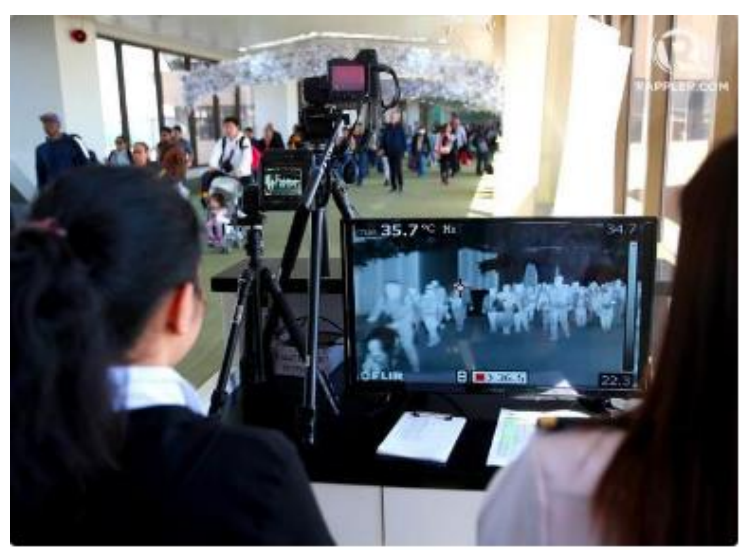

Gambar 4. Thermal Scanner Camera 


\section{Cara Kerja Thermal Scanner Camera}

Setiap kali ada virus yang menyerang tubuh manusia, kamera ini yang selalu menjadi andalan dalam mencegah virus tersebut. Di Indonesia sendiri, telah dipasang Thermal Scanner Camera ini pada 135 pintu masuk Indonesia kedatangan internasional terkait virus corona. Alat ini bekerja dengan cara mendeteksi suhu tubuh siapapun yang melintas di depan kamera ini. Kamera ini bekerja mendeteksi suhu tubuh manusia dengan menyorot sinar infra merah. Alat ini diatur adar bisa memindai suhu tubuh diatas 38 derajat celcius. Seseorang dengan suhu tubuh yang lebih tinggi dari angka tersebut bisa dipastikan terjangkit infeksi baik oleh bakteri ataupun virus. Alat ini tidak bisa memindai penyakit pada suh $\mathrm{u}$ tubuh seseorang, namun alat ini dapat membantu para petugas medis yang ada di bandara untuk melakukan pengecekan lebih lanjut jika ada seseorang yang teridentifikasi memiliki suhu tubuh diatas angka normal.

Cara kerja kamera ini adalah dengan mendeteksi suhu tubuh dengan mengenali dan menangkap berbagai tingkat cahaya inframerah. Cahaya ini tidak dapat dilihat oleh mata, tetapi dapat dirasakan sebagai panas jika memliki intensitas yang cukup tinggi. Semakin panas suatu objek maka akan semakin banyak radiasi infra merah yang akan dihasilkan. Thermal scanner dapat melihat radiasi ini dan mengubahnya menjadi gambar yang kemudian dapat dilihat dengan mata melalui monitor dan alarm akan berbunyi sehingga petugas akan segera memeriksa lebih lanjut orang yang memiliki suhu tubuh diatas angka normal. Perangkat ini dapat merekam suhu dengan warna-warna yang berbeda yang bisa dijadikan sebagai indikator. Suhu yang lebih dingin akan diberi warna biru, ungu, atau hijau. Sedangkan suhu yang lebih tinggi akan diberi warna merah, oranye atau kuning. Selain itu, kamera ini memiliki ukuran yang besar sehingga tidak
Kamera ini sangat membantu pemerintah dalam mencegah masuknya virus corona ke Indonesia.

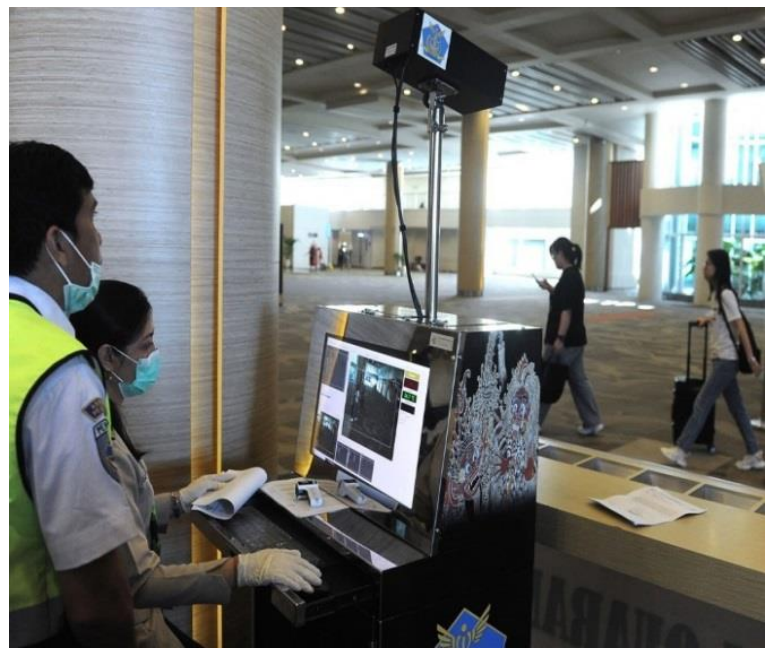

Gambar 5. Melakukan Pengecekan

Penumpang Menggunakan Thermal Scanner Camera pada bandara SoekarnoHatta

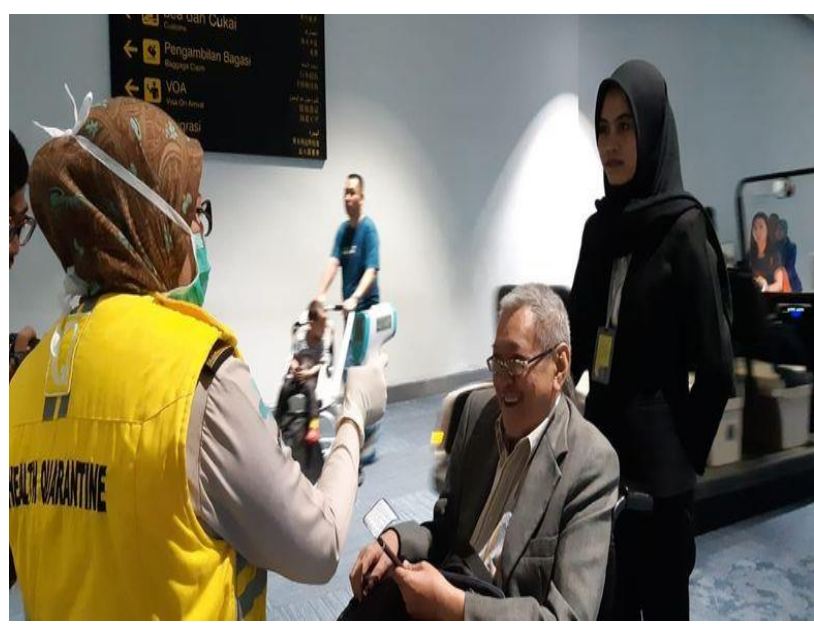

Gambar 6. Pengecekan Penumpang Menggunakan Thermal Gun pada bandara Soekarno-Hatta

\section{SIMPULAN}

Artificial Intellegence mampu mengidentifikasi suhu tubuh sehingga dapat membantu pemerintah untuk mencegah penyebaran virus apapun yang sedang menyerang tubuh. Selain itu terdapat beberapa kit yang dibuat untuk melihat langsung apakah penumpang 
terjangkit virus corona atau tidak Identifikasi virus corona dengan menggunakan artificial intellegence yang didukung oleh kamera thermal scanner dapat membantu petugas bandara dalam melakukan pengecekan virus corona pada setiap penumpang kedatangan internasional.

\section{DAFTAR PUSTAKA}

[1] M.Dahria, "Kecerdasan Buatan (Artificial Intellegence)". Jurnal SAINTIKOM. Vol.5, No.2 Agustus 2008.

[2] A. Zein, "Pendeteksian Virus Corona Dalam Gambar X-Ray Menggunakan Algoritma Artificial Intelligence Deep Learning Pyhton”. Jurnal Teknologi Informasi ESIT. Vol.XV, No. 01 April 2020.

[3] D.Kurnia, "Identikasi Obesitas Pada Balita Di Posyandu Berbasis Artificial Intellegence". Jurnal Sains Dan Informatika V4.11(76-86). 18 April 2018

[4] Iwan A Sunadi dkk, "Strategi Teknologi dan Manajemen Invoasi : Aplikasi Artificial Intelligence Untuk Keberlanjutan Produksi Gliserol Ester" . Jurnal Teknik Industri ISSN: 1411-6340.
[5] A.D.Putri, D. Pratama, "Sistem Pakar Mendeteksi Tindak Pidana Cybercrime Menggunakan Metode Forward Chaining Berbasis Web Di Kota Batam". Jurnal Edik Informatika ISSN:2407-0491, eISSN:2541-3716.

[6] Saluky, "Tinjauan Artificial Intelligence untuk Smart Goverment". ITEJ. Vol.03-No.01 2018, eISSN:2548-2157.

[7] A. Susilo dkk, "Coronavirus Disease 2019: Tinjauan Literatur Terkini". Jurnal Penyakit Dalam Indonesia. Vol. 7, No. 1 Maret 2020.

[8] K.Irawan, "Deteksi Manusia Menggunakan Webcam Pada Aplikasi Berbasis Kecerdasan Buatan".

[9] A.R. Wasril dkk, "Pembuatan Pendeteksi Obyek Dengan Metode You Only Look Once (YOLO) Untuk Automated Teller Machine (ATM)". Majalah Ilmiah UNIKOM. Vol.17, No.1.

[10] M.I.Moha, dkk, “Implementasi Kamera 360 Derajat Untuk Mendeteksi Objek Pada Robot Sepak Bola Beroda". Jurnal Teknik Informatika. Vol.14, No.3. EISSN:2685-6131, PISSN:23018402, Juli-September 2019. 